\title{
The Use of Teat-End Hyperkeratosis to Predict Somatic Cell Count and Milk Quality of Holstein Cows Raised in Egypt
}

\author{
S. Abdelghany, N. H. Fahim, F. Samir, \& M. A. Radwan* \\ Department of Animal Production, Faculty of Agriculture, Cairo University, Giza, Egypt \\ ${ }^{*}$ Corresponding author: m.radwan883@agr.cu.edu.eg \\ (Received 27-08-2020; Revised 12-10-2020; Accepted 04-11-2020)
}

\begin{abstract}
The study aimed to investigate the association between teat-end hyperkeratosis (THK) and somatic cell count (SCC) and to assess the effect of SCC on milk yield, fat, and protein percentages of Holstein cows. A total of 740 udder quarters of 185 Holstein cows kept in three commercial herds in Egypt were enrolled in the study from May to September 2019. Foremilk samples were collected from udder quarters for assessing milk SCC, fat, and protein percentages. On the same cows, a digital picture of each teat end orifice was taken with a digital camera. Cows' teats were assessed for THK and classified into two different groups of hyperkeratosis; mild and severe THK. SCC was converted to five classes of somatic cell score (SCS). Simple linear regression was performed to determine the loss of milk yield, fat, and protein percentages. SCC was significantly affected by THK $(\mathrm{p}<0.0001)$. About $57 \%$ of teats were classified as mild THK and $43 \%$ as severe THK. The teats with severe THK recorded higher SCC in milk. It was observed that SCS had a significant effect on fat and protein percentages $(p<0.0001)$. A similar trend was shown for the effect of SCS on milk yield $(p<0.05)$, where the highest values of milk traits were obtained for the lowest SCS. The loss of milk was $220 \mathrm{~g} / \mathrm{day}$. Also, fat and protein percentages decreased by $0.11 \%$ and $0.08 \%$, respectively, for each unit increase in SCS, from zero to four. In conclusion, severe THK can lead to high SCC, which negatively affects milk traits.
\end{abstract}

Keywords: hyperkeratosis; milk quality; Holstein; Egypt; somatic cell count

\section{INTRODUCTION}

Mastitis is considered as the main cause of economic losses in dairy farms in terms of treatment costs, milk quantity, and quality reduction (Le Maréchal et al., 2011; Ruegg \& Pantoja, 2013). The incidence of mastitis can be linked with the cow (internal factors), including breed, stage of lactation, parity, milk yield, reproductive problems, and teat and udder conformation. Also, there are factors related to farm management aspects (external factors) such as animal housing, nutrition, udder hygiene, and milking practices (De Vliegher et al., 2012; Miles et al., 2019).

Pinzón-Sánchez \& Ruegg (2011) reported that the clinical mastitis (CM) symptoms were graded as mild (abnormal milk, such as clotted milk), moderate (abnormal appearance of milk accompanied by the mammary gland swelling or redness), and severe (changes in milk secretion, mammary gland, and health disorders such as fever). While Vissio et al. (2014) reported that sub-clinical mastitis (SCM) is represented up to $80 \%$ of the total losses of mastitis disease and is usually demonstrated as an elevation of the SCC. SCM diagnostic approaches are usually based on SCC measurements, where somatic cells are the reflection of resistance and sensitivity of cows to mastitis, particularly SCM (Sharma et al., 2011). Also, SCC is a useful diagnostic tool to detect intra- mammary infection and as milk assessment in terms of quality, hygiene, and mastitis control (Alhussien \& Dang, 2018a). Somatic cells consist of white blood cells (leukocytes) and epithelial cells, which represent about $75 \%$ and $25 \%$, respectively. Whereas the function of white blood cells is engulfing and killing bacteria (Sharma et al., 2011). Milk from uninfected cows typically has SCC $<200,000$ cells $/ \mathrm{mL}$, while cows with SCC $\geq 200,000$ per $\mathrm{mL}$ of milk without clinical symptoms are considered SCM cases (Smith et al., 2001), while the Egyptian standards considered udder is affected by SCM when SCC exceeds 500,000 cells/mL (Egyptian standards of raw milk, 2010).

Somatic cells represent the second line of defense against intra-mammary infection like mastitis, while the primary line of defense is the teat apex and teat canal, so keeping teat skin and teat-end integral is an essential part of successful mastitis prevention (Alhussien \& Dang, 2018a). The factors influencing the teat-end changes can be divided into two groups of factors: the first group associated with a cow, which includes teatend form, the length of the teat, milk yield, days in milk, and parity (Neijenhuis et al., 2000). The second group is linked with machine factors such as vacuum level, slow or overmilking, and pulsation rate, in addition to harsh weather conditions (Mein et al., 2001). 
Mein et al. (2001) classified changes in the teat-end condition into four categories: (1) Short-term effects include the change in teat color, teat swelling, hardness, and teat orifice; (2) Medium-term effects include change in teat skin condition and vascular injury; (3) Longerterm effects include change in THK; and (4) Very longterm effects include the change in teat size and tissue fibrosis. Moreover, the researchers defined THK as a thickening of the skin that lines the teat canal and surrounds the external teat orifice, and it was classified into four categories: no ring, slightly rough ring, rough, and very rough.

Holstein is the most recognized and common dairy breed in the world. It is considered the most predominant exotic dairy breed in the commercial herds in Egypt. Most studies on Holstein in Egypt focused on productive and reproductive performance. Detecting mastitis depended on measuring milk SCC or California Mastitis Test (CMT), with no available reports depicting a relationship between THK and SCC under the Egyptian conditions. Therefore, the objectives of this study were to investigate the relationship between THK score and milk SCC and to assess the effect of SCC on milk yield, fat $\%$, and protein $\%$ of Holstein cows raised in three commercial herds in Egypt.

\section{MATERIALS AND METHODS}

\section{Study Location}

This study was conducted on three commercial dairy farms in Egypt during the period from May to September 2019. The first farm is located in Alexandria Governorate $(220 \mathrm{~km}$ northwest of Cairo, at a latitude $31^{\circ} 12^{\prime} 56.3^{\prime \prime} \mathrm{N}$ and a longitude $\left.29^{\circ} 57^{\prime} 18.97^{\prime \prime} \mathrm{E}\right)$; the second farm is located in Sharqia Governorate $(115 \mathrm{~km}$ northeast of Cairo, at a latitude $30^{\circ} 36^{\prime} 58.25^{\prime \prime} \mathrm{N}$ and a longitude $31^{\circ} 44^{\prime} 6.50^{\prime \prime} \mathrm{E}$ ) and the third farm is located in Fayoum Governorate (120 km southwest of Cairo, at a latitude $29^{\circ} 18^{\prime} 35.82^{\prime \prime} \mathrm{N}$ and a longitude $\left.30^{\circ} 50^{\prime} 30.48^{\prime \prime} \mathrm{E}\right)$.

\section{Animals}

A total number of 185 Holstein cows were enrolled in this study. Cows in the three farms were in the first 100 days of lactation and from the first to the fourth parity. Cows participating in the study didn't show any visible signs of clinical mastitis such as swelling, heat, and hardness or abnormalities in milk such as watery appearance, flakes, or clots. Regarding animal ethical code of ethics, all participated authors followed the international, national, and institutional guidelines (Institutional Animal Care and Use Committee (CUIACUC), Cairo University with approval number: (CU II F 31 20) for humane animal treatment and complied with relevant legislation.

\section{Herd Management}

Management practices in the three farms were almost similar, where the cows were housed in free-stall barns with a sandy floor and shaded with corrugated metal sheets. Animals were fed total mixed ration (TMR) throughout the year, according to National Research Council requirements. The TMR consisted of corn, soybean, wheat bran, corn silage, alfalfa hay, and vitamins and minerals supplementation. Rations were given three times a day, and freshwater was available all day. Cows were machine milked three times daily in all farms at intervals of 8 hours, beginning at 05:00 am. The milking routine that was applied in Sharqia and Fayoum Farms was foremilk stripping, pre-dipping the teats, drying the teats with a clean, dry cloth or towel, attaching the milking unit, and post-dipping. Alexandria farm was conducted the same milking routine with washing udder as additional practice and then wiped the teats with a towel per cow before stripping step to ensuring no water remained on the udder. The milking vacuum level in the three farms was set at $42 \mathrm{kPa}$. The daily milk yield of the enrolled cows in three farms was recorded using a herd management software system (Dairy Comp 305).

\section{Milk Sampling and Analysis}

Milk sampling was using sterile tubes. $50 \mathrm{~mL}$ of foremilk samples were collected during the second milking (at 01:00 pm) from 740 udder quarters. Milk samples were kept in the icebox until transport to the laboratory at the Faculty of Agriculture, Cairo University. Samples were stored at $4^{\circ} \mathrm{C}$ and analyzed within 6-12 hours after collection. Fat \%, protein \%, and SCC were analyzed using Lactoscan MCC Combo, Ultrasonic milk analyzer, and somatic cell counter in one device (Stara Zagora, Bulgaria). Cows participating in this study were inspected just once.

\section{Somatic Cell Score (SCS)}

To achieve the normality of distribution, SCC had been transformed to SCS according to the equation of Ali \& Shook (1980) as follows: SCS $=\log _{2}(\mathrm{SCC} / 100,000)$ +3 . Values of SCS were: (0) $<25,000 \mathrm{SCC} / \mathrm{mL}$; (1) $=25,000: 49,999 \mathrm{SCC} / \mathrm{mL}$; (2) $=50,000: 99,999 \mathrm{SCC} / \mathrm{mL}$; (3) $=100,000: 199,999$ SCC/mL; (4) $\geq 200,000 \mathrm{SCC} / \mathrm{mL}$. The same authors add that the advantage of this scale (SCS) was associated linearly to losses due to mastitis infection in milk yield.

\section{Teat-End Hyperkeratosis (THK)}

THK is a term used to describe a thickened smooth keratin ring or extending fronds of keratin around the teat orifice. To identify changes in teat end for roughness and callosity, THK was assessed and classified. THK was evaluated immediately after milking and before post-dipping of teats. All observations were carried out by the same person. THK was classified into four categories (Figure 1) according to Mein et al. (2001) as follows: class 1 (no ring), which means smooth teat end with a small even orifice; class 2 (smooth or slightly rough ring), which means a raised ring around the orifice with no roughness or slightly rough and no fronds of old keratin; class 3 (rough ring), which means a raised roughened ring with isolated fronds of old keratin ex- 


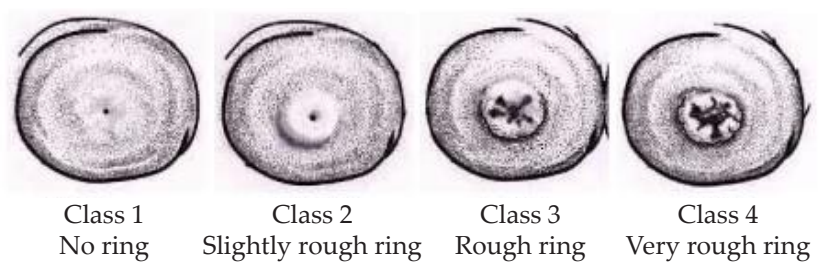

Figure 1. Scoring system for teat-end hyperkeratosis (Mein et al., 2001).

tending $1-3 \mathrm{~mm}$ from the orifice; and class 4 (very rough ring), which means the rim of the ring roughened and cracked with old keratin extending more than $4 \mathrm{~mm}$ from the orifice.

Emre \& Alaçam (2015) studied Holstein cows and evaluated THK into six classes: (0) Normal teat-end orifice, (1) Smooth ring, (2) Slightly rough ring of keratin, (3) Moderate raised, smooth ring, (4) Rough ring, and (5) Very rough ring. The authors merged the six classes of THK into three categories: (1) Normal teats, (2) Mild hyperkeratosis, and (3) Severe hyperkeratosis.

In the present study, it was difficult to differentiate between classes 1 and 2 when assessing the most teats. So, we merged them into one category. The same was done for classes 3 and 4 . Thus, the four classes were combined with being two categories, category 1 (no ring and slightly rough ring teats) versus category 2 (rough ring and very rough ring teats). THK scoring was detected via the photography method with a digital camera Kaiser Baas X4 Action Camera (12-megapixel resolution 4000x3000 4:3; Melbourne, Australia). The photos of THK were uploaded to a computer and scored in the laboratory instead of the direct optical assessment in the milking parlor to avoid interference with milking routines. Subsequently, results of individual SCC were matched with a score of THK. The distribution of udder quarters, according to the parameters under study, is presented in Table 1.

\section{Studied Traits}

1- Quarter daily milk yield (QDMY): This trait was calculated according to Bogucki (2018) as follows: right front quarter produced $21.3 \%$, left front quarter $21.3 \%$, right rear quarter $28.6 \%$, and left rear quarter $28.8 \%$ of the cow's total daily milk yield. 2- Somatic Cell Count (SCC). 3- Milk Fat percentage. 4- Milk Protein percentage.

\section{Statistical Analysis}

Data were analyzed using XLSTAT version 2019.1.2. according to the two subsequent models:

Model 1: was used for analyzing SCC.

$\mathrm{Y}_{\mathrm{ijklm}}=\mu+\mathrm{T}_{\mathrm{i}}+\mathrm{F}_{\mathrm{j}}+\mathrm{P}_{\mathrm{k}}+\mathrm{Q}_{1}+\mathrm{e}_{\mathrm{ijklm}}$.

where, $Y_{i j k l m}$ was SCC in each quarter per each cow; $\mu=$ overall mean, $T_{i}$ was the effect of the ith THK $(i=1,2)$; where 1 was no ring or slightly rough ring teat, and 2 was rough or very rough ring teat, $F_{i}$ was the effect of the $j$ th farm $(j=1,2,3)$; where 1 was Alexandria, 2 was
Sharqia, and 3 was Fayoum; $\mathrm{P}_{\mathrm{k}}$ was the effect of the kth parity $(k=1,2,3,4) ; Q_{1}$ was the effect of the lth quarter position $(1=1,2,3,4)$; where 1 was right front, 2 was left front, 3 was right rear, and 4 was left rear); and $e_{i j k l m}$ was a random residual effect.

Model 2: was used for analyzing QDMY and fat and protein percentages. $\mathrm{Y}_{\mathrm{ijkl}}=\mu+\mathrm{S}_{\mathrm{i}}+\mathrm{F}_{\mathrm{j}}+\mathrm{P}_{\mathrm{k}}+\mathrm{e}_{\mathrm{ijk}}$. where, $Y_{i \mathrm{jkl}}$ was dependent variables; $\mu$ was overall mean; $S_{i}$ was the effect of the ith SCS $(i=0,1,2,3,4)$; where $0<25,000 \mathrm{SCC} / \mathrm{mL}, 1=25,000: 49,999 \mathrm{SCC} / \mathrm{mL}$, $2=50,000: 99,999 \mathrm{SCC} / \mathrm{mL}, \quad 3=100,000: 199,999 \mathrm{SCC} / \mathrm{mL}$, and $4 \geq 200,000 \mathrm{SCC} / \mathrm{mL} ; \mathrm{F}_{\mathrm{j}}$ was the effect of the jth farm $(j=1,2,3)$; where 1 was Alexandria, 2 was Sharqia, and 3 was Fayoum; $\mathrm{P}_{\mathrm{k}}$ was the effect of the kth parity $(\mathrm{k}=1,2$, $3,4)$; and $\mathrm{e}_{\mathrm{ijkl}}$ was residual error.

All possible interactions were tested and found not significant; therefore, they were excluded from the models. Simple linear regression of QDMY and fat and protein percentages on SCS classes were studied to assess the effect of SCS on milk yield, fat $\%$, and protein $\%$.

\section{RESULTS}

\section{Somatic Cell Count (SCC)}

The least-squares means and standard errors of SCC as affected by THK, farm, parity, and udder quar-

Table 1. Percentage distribution of the udder quarters according to parameters studied

\begin{tabular}{cll}
\hline \multicolumn{1}{c}{ Variables } & \multicolumn{1}{c}{ No. } & Percentage \\
\hline THK & & \\
1 & 425 & 57.40 \\
2 & 315 & 42.60 \\
SCS & & \\
0 & 238 & 32.16 \\
1 & 80 & 10.81 \\
2 & 89 & 12.03 \\
3 & 105 & 14.19 \\
4 & 228 & 30.81 \\
Farm & & \\
Alexandria & 280 & 37.84 \\
Sharqia & 340 & 45.94 \\
Fayoum & 120 & 16.22 \\
Parity & & \\
$1^{\text {st }}$ & 196 & 26.49 \\
$2^{\text {nd }}$ & 288 & 38.92 \\
$3^{\text {rd }}$ & 108 & 14.59 \\
$4^{\text {th }}$ & 148 & 20.00 \\
Quarter position & & \\
Right front & 185 & 25.00 \\
Left front & 185 & 25.00 \\
Right rear & 185 & 25.00 \\
Left rear & 185 & 25.00 \\
\hline & & \\
\hline
\end{tabular}

Note: $\mathrm{THK}=$ Teat-end hyperkeratosis $(1=$ no ring or slightly rough ring teat, $2=$ rough or very rough ring teat); $\mathrm{SCS}=$ Somatic cell score ( $0<25,000$ Somatic cell count, $1=25,000: 49$, 999 SCC, $2=50,000: 99,999$ SCC, $3=100,000: 199,999$ SCC, $4 \geq 200,000$ SCC); No.= number of udder quarters. 
ter position were presented in Table 2. The overall mean of SCC was about 195,000 cells/mL. THK had a significant effect $(\mathrm{p}<0.0001)$ on SCC. The highest mean of SCC was observed with the score 2 (442,657 cells /mL), representing $42.6 \%$ of the total examined teats. Furthermore, SCC was significantly influenced by the farm $(p<0.003)$. The lowest mean of SCC was about 175,000 cells/mL in Alexandria farm.

Table 2 shows that there was no significant effect between parity and udder quarter position on SCC. Where, the lowest milk SCC was recorded during the second parity $(213,750$ cells/mL), while the highest SCC value was observed in the fourth one $(302,024$ cells/mL). Regarding udder quarter position, the values of SCC in the four quarters ranged from 220,000 cells/mL (in right front) to 305,000 cells/mL (in right rear).

\section{Quarter Daily Milk Yield (QDMY)}

The least-squares means and standard errors of QDMY as affected by SCS, farm, and parity were presented in Table 3. The overall mean of QDMY was $6.14 \mathrm{~kg}$, which means that the average daily milk yield is about $25 \mathrm{~kg}$ for each cow in the three farms. The SCS significantly affected QDMY $(\mathrm{p}<0.05)$. The values of QDMY ranged from $6.14 \mathrm{~kg}$ for score zero (SCC $<25,000 /$ $\mathrm{mL}$ ) to $5.22 \mathrm{~kg}$ for score 4 (SCC $\geq 200,000 / \mathrm{mL}$ ) (Table 3).

The farm had a significant effect $(p<0.0001)$ on QDMY, Alexandria farm had a higher value for QDMY $(6.94 \mathrm{~kg})$ than the other two farms, this may be attributed to the lowest milk SCC of Alexandria farm $(175,000$

Table 2. Least-squares means (LSM) and standard error (SE) of somatic cell count (SCC) as affected by teat-end hyperkeratosis, farm, parity, and udder quarter position

\begin{tabular}{lccc}
\hline \multirow{2}{*}{ Classification } & \multirow{2}{*}{ No. } & \multicolumn{2}{c}{ SCC $/ \mathrm{mL}$} \\
\cline { 3 - 4 } & & $\mathrm{LSM} \pm$ SE & P-value \\
\hline Overall mean & 740 & $194,891 \pm 16,939$ & \\
THK & & & \\
$\quad 1$ & 425 & $66,861 \pm 24,000^{\mathrm{a}}$ & \\
2 & 315 & $442,657 \pm 25,924^{\mathrm{b}}$ & \\
Farm & & & 0.003 \\
$\quad$ Alexandria & 280 & $175,191 \pm 31,711^{\mathrm{a}}$ & \\
$\quad$ Sharqia & 340 & $256,151 \pm 26,915^{\mathrm{ab}}$ & \\
$\quad$ Fayoum & 120 & $332,935 \pm 35,254^{\mathrm{b}}$ & \\
Parity & & & 0.270 \\
$\quad 1^{\text {st }}$ & 196 & $246,816 \pm 34,108$ & \\
$2^{\text {nd }}$ & 288 & $213,750 \pm 27,981$ & \\
$3^{\text {rd }}$ & 108 & $256,445 \pm 44,946$ & \\
$\quad 4^{\text {th }}$ & 148 & $302,024 \pm 36,754$ & \\
Quarter position & & & 0.210 \\
$\quad$ Right front & 185 & $219,364 \pm 35,214$ & \\
$\quad$ Left front & 185 & $225,992 \pm 33,727$ & \\
$\quad$ Right rear & 185 & $305,658 \pm 32,864$ & \\
$\quad$ Left rear & 185 & $268,022 \pm 32,593$ & \\
\hline
\end{tabular}

Note: $\mathrm{THK}=$ Teat-end hyperkeratosis $(1=$ no ring or slightly rough ring teat, $2=$ rough or very rough ring teat); No.= number of udder quarters. Means in the same column with different superscripts differ significantly $(\mathrm{p}<0.05)$. cells $/ \mathrm{mL}$ ). In contrast, the Fayoum farm had the lowest value of QDMY $(3.86 \mathrm{~kg})$, which could be associated with the highest SCC value, i.e., 332,935 cells/mL (see Table 2).

Parity also had a significant effect $(p<0.001)$ on QDMY, which increased gradually by increasing the parity number. The lowest QDMY was found with the first parity $(5.28 \mathrm{~kg})$, while the highest QDMY was observed in the fourth $(6.28 \mathrm{~kg})$.

\section{Fat and Protein Percentages}

The least-squares means and standard errors of fat and protein percentages as affected by SCS, farm, and parity are presented in Table 4 . The overall means of fat and protein percentages in foremilk were $2.80 \%$ and $3.51 \%$, respectively, of studied Holstein cows. SCS had a significant effect $(\mathrm{p}<0.0001)$ on fat and protein percentages, where the highest values of fat and protein percentages were obtained with SCS class zero (SCC $<25,000$ cells $/ \mathrm{mL}$ ), and the lowest values of fat and protein percentages were observed with SCS class 4 (SCC $\geq 200,000$ cells/mL).

The farm had a significant effect on the fat percentage $(p<0.001)$, but there was no significant effect on protein percentage. The highest fat percentage was found at Fayoum farm $(2.93 \%)$, and the lowest value was recognized in Alexandria farm (2.68\%). However, parity had no significant effect on the percentages of fat and protein. The first parity showed the highest fat percentage value after that, and fat content tended to decrease in the next parities (Table 4).

Table 3. Least-squares means (LSM) and standard error (SE) of quarter daily milk yield (QDMY) as affected by somatic cell score, farm, and parity

\begin{tabular}{|c|c|c|c|}
\hline \multirow{2}{*}{ Classification } & \multirow{2}{*}{ No. } & \multicolumn{2}{|c|}{$\mathrm{SCC} / \mathrm{mL}$} \\
\hline & & $\mathrm{LSM} \pm \mathrm{SE}$ & P-value \\
\hline Overall mean & 740 & $6.14 \pm 0.13$ & \\
\hline SCS & & & $<0.05$ \\
\hline 0 & 238 & $6.14 \pm 0.21^{\mathrm{a}}$ & \\
\hline 1 & 80 & $5.91 \pm 0.31^{\mathrm{ab}}$ & \\
\hline 2 & 89 & $5.70 \pm 0.28^{\mathrm{ab}}$ & \\
\hline 3 & 105 & $5.53 \pm 0.33^{\mathrm{ab}}$ & \\
\hline 4 & 228 & $5.22 \pm 0.19^{b}$ & \\
\hline Farm & & & $<0.0001$ \\
\hline Alexandria & 280 & $6.94 \pm 0.19^{a}$ & \\
\hline Sharqia & 340 & $6.31 \pm 0.15^{\mathrm{b}}$ & \\
\hline Fayoum & 120 & $3.86 \pm 0.21^{c}$ & \\
\hline Parity & & & $<0.001$ \\
\hline $1^{\text {st }}$ & 196 & $5.28 \pm 0.20^{a}$ & \\
\hline $2^{\text {nd }}$ & 288 & $5.37 \pm 0.22^{\mathrm{a}}$ & \\
\hline $3^{\text {rd }}$ & 108 & $5.88 \pm 0.25^{\mathrm{ab}}$ & \\
\hline $4^{\text {th }}$ & 148 & $6.28 \pm 0.17^{b}$ & \\
\hline $\begin{array}{c}\text { Note: } \mathrm{SCS}=\text { Somatic } \\
1=25,000: 49,999 \\
\text { SCC, } 4 \geq 200,000 \\
\text { the same colum } \\
(\mathrm{p}<0.05) .\end{array}$ & $\begin{array}{r}\text { cell } \quad \mathrm{sc} \\
\mathrm{SCC}, 2= \\
\mathrm{SCC}) ; \mathrm{No}= \\
\text { n with di }\end{array}$ & $\begin{array}{l}\text { (0<25,000 Son } \\
0: 99,999 \text { SCC, } \\
\text { mber of udder } \\
\text { nt superscripts }\end{array}$ & $\begin{array}{l}\text { cell count } \\
0,000: 199,999 \\
\text { rs. Means in } \\
\text { significantly }\end{array}$ \\
\hline
\end{tabular}




\section{Regression Analysis}

Based on a simple linear regression analysis of QDMY and fat and protein percentages on SCS, the following equations have resulted from the regression analysis:

The first equation. $y=-0.220 x+6.367,\left(R^{2}=0.991\right)$

Where y was dependent variable (QDMY), (-0.220) was the regression coefficient of QDMY on SCS, which determines the amount of decrease in QDMY due to the increasing SCS, by one unit from zero to four to be $220 \mathrm{~g}$ (Figure 2), x was independent variable (SCS), and (6.367) was the intercept.

The second equation. $y=-0.116 x+2.992,\left(R^{2}=0.995\right)$
Where y was dependent variable (Fat $\%),(-0.116)$ was the regression coefficient of fat $\%$ on SCS, which determines the amount of decrease in fat percentage at the quarter level due to increasing SCS, by one unit from zero to four equals to $0.11 \%$ (Figure 3 ), $x$ was independent variable (SCS), and (2.992) was the intercept.

The third equation. $y=-0.078 x+3.845,\left(R^{2}=0.961\right)$

Where y was dependent variable (Protein \%), (-0.078) was the regression coefficient of protein $\%$ on SCS, which determines the amount of decrease in protein percentage at the quarter level due to increasing SCS, by one unit from zero to four equals to $0.078 \%$ (Figure 3 ), $x$ was independent variable (SCS), and (3.845) was the intercept.

Table 4. Least-squares means (LSM) and standard error (SE) of fat and protein percentages as affected by somatic cell score, farm, and parity

\begin{tabular}{|c|c|c|c|c|c|}
\hline \multirow{2}{*}{ Classification } & \multirow{2}{*}{ No. } & \multicolumn{2}{|c|}{ Fat $\%$} & \multicolumn{2}{|c|}{ Protein \% } \\
\hline & & $\mathrm{LSM} \pm \mathrm{SE}$ & P-value & $\mathrm{LSM} \pm \mathrm{SE}$ & P-value \\
\hline Overall mean & 740 & $2.80 \pm 0.03$ & & $3.51 \pm 0.02$ & \\
\hline $\mathrm{SCS}^{3}$ & & & $<0.0001$ & & $<0.0001$ \\
\hline 0 & 238 & $2.90 \pm 0.05^{\mathrm{a}}$ & & $3.74 \pm 0.04^{\mathrm{a}}$ & \\
\hline 1 & 80 & $2.83 \pm 0.07^{\mathrm{ab}}$ & & $3.60 \pm 0.05^{b}$ & \\
\hline 2 & 89 & $2.80 \pm 0.07^{\mathrm{ab}}$ & & $3.51 \pm 0.05^{b}$ & \\
\hline 3 & 105 & $2.67 \pm 0.06^{\mathrm{cb}}$ & & $3.37 \pm 0.05^{c}$ & \\
\hline 4 & 228 & $2.58 \pm 0.05^{c}$ & & $3.27 \pm 0.04^{c}$ & \\
\hline Farm & & & 0.001 & & 0.741 \\
\hline Alexandria & 280 & $2.68 \pm 0.05^{\mathrm{b}}$ & & $3.50 \pm 0.03$ & \\
\hline Sharqia & 340 & $2.66 \pm 0.04^{\mathrm{b}}$ & & $3.49 \pm 0.03$ & \\
\hline Fayoum & 120 & $2.93 \pm 0.05^{\mathrm{a}}$ & & $3.47 \pm 0.04$ & \\
\hline Parity & & & 0.071 & & 0.654 \\
\hline $1^{\text {st }}$ & 196 & $2.84 \pm 0.05$ & & $3.50 \pm 0.04$ & \\
\hline $2^{\text {nd }}$ & 288 & $2.76 \pm 0.04$ & & $3.47 \pm 0.03$ & \\
\hline $3^{\text {rd }}$ & 108 & $2.74 \pm 0.06$ & & $3.51 \pm 0.04$ & \\
\hline $4^{\text {th }}$ & 148 & $2.68 \pm 0.05$ & & $3.52 \pm 0.04$ & \\
\hline
\end{tabular}

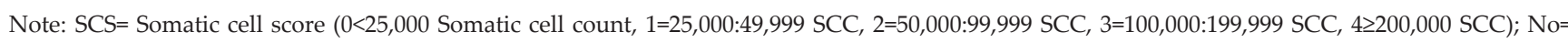
number of udder quarters. Means in the same column with different superscripts differ significantly $(p<0.05)$.

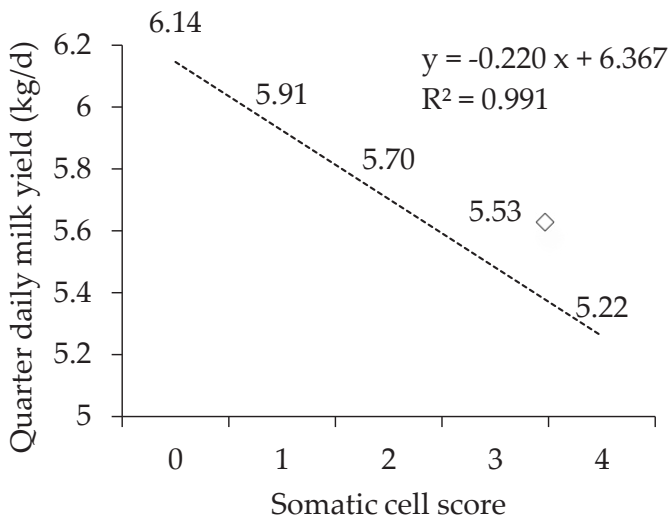

Figure 2. Effect of somatic cell score on quarter daily milk yield $(-\diamond-)$



Figure 3. Effect of somatic cell score on fat $\%(-\Delta-)$ and protein $\%$ $(-\square-)$. 


\section{DISCUSSION}

\section{Somatic Cell Count (SCC)}

The classification of THK into scores can be useful as an important tool to identify the role of THK as a risk factor for the incidence of mastitis (Manzi et al., 2012). In this study, udder quarters with severe THK have a higher SCC. This result is similar to that found by Emre \& Alaçam (2015) on Holstein cows, who reported that a severe THK was associated with SCC $\geq 200,000$ cells $/ \mathrm{mL}$. Mitev et al. (2012); Cardozo et al. (2015); Juozaitiene et al. (2019) showed an extreme degree of hyperkeratosis associated with an increase of milk SCC as a reaction to intramammary infection such as subclinical mastitis. Mein (2012) interpreted the increase of SCC with a severe THK because teats with thickness or roughness have less tightly teat canals after milking, so they can be penetrated more easily by microorganisms. In contrast, the study conducted by Zoche-Golob et al. (2015) on Holstein cows in Germany concluded that there was no effect of various THK scores on the risk of new intramammary infections or mastitis.

All farms performed almost the same milking routine, but in Alexandria farm, there was better control during milking, and bedding was cleaner than that of the other two farms. This result explains the importance of applying a good milking routine as well as good environmental hygiene in dairy farms. The significant effect of the farm on SCC were also by Sadeghi-sefidmazgi \& Rayatdoost-baghal (2014), Sandrucci et al. (2014), Cardozo et al. (2015) in Holstein dairy farms.

Although SCC increased with the increasing number of parities, the differences did not reach the level of significance. A similar result was mentioned by Alhussien \& Dang (2018b) on Karan Fries (HolsteinFriesian $\times$ Tharparkar) cows in India. They found no differences in milk SCC up to the fourth parity, but for cows with more than four parities, SCC increased significantly. Mitev et al. (2012) observed a higher milk SCC with an increasing parity number, which could be due to the longer effect of the milking machine and occurring teat end changes, promoting the invasion of bacteria and thus increasing SCC. The significant effect of parity on SCC was also reported by (Asadpour et al., 2015; Sebastino et al., 2020).

The effect of the udder quarter position on SCC was not significant, although the rear quarters had higher SCC than the front quarters. The same conclusion was found by Schwarz et al. (2010); Badiuzzaman et al. (2015); Singh et al. (2017), studied on Holstein Friesian cows, crossbred dairy cows (Sahiwal $\times$ Deshi), and Frieswal dairy cows, in Germany, Bangladesh, and India, respectively. The authors attributed the association between increasing SCC and rear quarters may be due to rear quarter teats are often closer to the floor, particularly in older cows, and would, therefore, be more readily contaminated or injured with greater exposure to environmental effects. Guarín et al. (2017) in Wisconsin, USA, on Holstein cows, demonstrated that teat length and teat-end shape were not associated with SCC, while there was a tendency for the reduced SCC with the increased teat barrel diameter regardless of quarter position. Manzi et al. (2012) also stated that there was no association between susceptibility to mastitis and teat-end shape. On the contrary, Miles et al. (2019) studied Holstein cows in New York, observed that teats with a flat teat-end shape were associated with elevated SCC and more susceptible to mastitis. Also, Sharma et al. (2016) concluded that inverted and flat teat-end shape and large teat length had a significant incidence of SCM, in Tharparkar cows in India.

\section{Quarter Daily Milk Yield (QDMY)}

The results of our study indicate that the QDMY decreased by increasing SCS. The percentage of samples of score 4 equals about 30\%. Silva et al. (2018); Franzoi et al. (2019) in Brazil and Italy, respectively, reported similar findings to those observed in this study for decreasing milk yield with the increase of SCS in Holstein cows. A decrease in milk yield with an increase of SCS is attributed to two main groups of reasons. The first group includes physical damage of epithelial cells in the udder, the mammary gland's synthetic and secretory ability would be substantially decreased (Le Maréchal et al., 2011). The second group involves change most energy orientation from milk production towards the immune system, and also decreased feed intake due to pain and less activity (Alhussien \& Dang, 2018b). Furthermore, cows do not return to their performance before mastitis. Even after antibiotic treatment, the milk yield level does not improve, where clinical mastitis was associated with a loss of about $400 \mathrm{~kg}$ of milk at the next lactation (Bar et al., 2007).

Management practices have been consistently related to SCC levels in milk, resulting in a positive or negative effect on milk production, so farmers need to develop their management practices to monitor subclinical mastitis. The current finding on the farm's effect on milk yield was confirmed by Sadek et al. (2014) on Holstein cows in Egypt.

There was a positive association between parity and QDMY. This result agrees with the findings of Yang et al. (2013), who stated that on Holstein cows in the north of China, daily milk yield in the first parity was lower than other parities $(\mathrm{p}<0.05)$, where the daily milk yield was 25.94, 28.45, 28.81, $29.05 \mathrm{~kg} /$ day in the first, second, third, and fourth parities, respectively. In another study carried out in Mexico, Ríos-Utrera et al. (2013) reported that milk yield per lactation and milk yield per day increased with increasing lactation number of Holstein Friesian and Brown Swiss cows.

\section{Fat and Protein Percentages}

The obtained overall means for fat and protein percentages estimated from the foremilk (2.80\%, $3.51 \%$ ) were close to those reported by Khatun et al. (2019), who found that the means of fat and protein percentages were $2.83 \%$ and $3.41 \%$, respectively, using foremilk samples from Holstein-Friesian cows in Australia. Most of the studies on raw milk composition of Holstein cows in Egypt reported that milk fat 
percentage ranged from $2.97 \%$ to $3.74 \%$ (Zeinhom et al., 2016; Nasr \& El-Tarabany, 2017). In a study of Holstein cows in Denmark, to investigate the effects of sampling time during milking on the concentration of milk components, including fat percentage, Nielsen et al. (2005) found that milk fat increases significantly as the milking process progresses. The findings in this study have shown a clear association between the increase of milk SCS and the decrease of fat and protein percentages. These results are in agreement with the findings of Franzoi et al. (2019), who found that the greatest values of fat and protein percentages were observed with the lowest SCS class for Holstein Friesian, Brown Swiss, and Simmental cows. Also, Kul et al. (2019) reported that high milk SCC was associated with a reduction in the content of milk fat and protein of Holstein cows. Milk fat globule membranes are susceptible to the action of lipase enzymes, produced by leukocytes that invade the mammary gland in response to infection. This leads to a breakdown of triglycerides, oxidation of fatty acids, and hydrolysis of lipoproteins, this is a reason that explains why fat percentage decreased by the increase of SCC (Le Maréchal et al., 2011). Also, the same authors reported that when milk SCC increases, protein profile changes, whey protein levels increase, and $\alpha$ - and $\beta$-casein decrease, and these changes may be due to the hydrolysis of milk protein, besides, synthesis of casein is reduced during mastitis.

Fayoum farm had the lowest daily milk yield (3.86 $\mathrm{kg})$, and Alexandria farm had the highest daily milk yield $(6.94 \mathrm{~kg})$. Thus, the Fayoum farm had the highest milk fat percentage. In other words, the fat percentage tended to increase with a decrease in milk production. Feltes et al. (2016); Wongpom et al. (2017) showed a significant negative correlation between milk yield and fat percentage on Holstein cows in Brazil and Thailand, respectively.

There was no significant effect of parity on fat and protein percentages. This result agrees with the findings of Gurmessa \& Melaku (2012), who reported the not significant differences among primiparous and multiparous cows in fat and protein percentages of milk, using crossbred Holstein Friesian cows in Ethiopia. Heinrichs et al. (2016) found that milk fat and protein percentages decreased by $0.2 \%$ and $0.03 \%$, respectively, each year from the first to the fifth lactation. This decline in fat and protein percentages could be attributed to increasing milk yield with advancing parity. In contrast, Kul et al. (2019) recorded a higher milk fat content in the second parity and subsequently decreased $(\mathrm{p}<0.05)$.

\section{Regression Analysis}

In the current study, there was a reduction in milk production by $220 \mathrm{~g} /$ day. Furthermore, fat and protein percentages decreased by $0.11 \%$ and $0.08 \%$, respectively, at the quarter level, for each SCS class higher than zero. Halasa et al. (2009) reported that the expected loss of milk production, fat, and protein for cows with SCC (200,000 cells $/ \mathrm{mL}$, corresponding to SCS $=4$ ) were 0.31 and $0.58 \mathrm{~kg} / \mathrm{d}$ for milk production, 9 and $13 \mathrm{~g} / \mathrm{d}$ for fat, and 6 and $10 \mathrm{~g} / \mathrm{d}$ for protein, for primiparous and mul- tiparous cows, respectively. With each SCS unit, more than one, milk production, fat, and protein decreased by $0.43,0.01$, and $0.01 \mathrm{~kg} / \mathrm{d}$, respectively (Franzoi et al., 2019). The same authors reported that very low SCC $<6,250$ cells/mL had negative effects on milk yield and quality. Therefore, SCC among 12,500:25,000 cells/ $\mathrm{mL}$ (SCS from zero to one) was considered the best SCS for milk yield and quality. Moreover, optimal SCS estimated $\left(R^{2}\right)$ for milk yield, fat, and protein percentages, based on a third-order polynomial regression, which resulted in $\mathrm{R}^{2} \geq 0.96(\mathrm{p}<0.001)$. Further studies are needed, with consideration of collecting monthly milk samples throughout the lactation period, which would likely provide a lot of information about THK or teatend condition as a diagnostic tool to monitoring udder health and milk quality.

\section{CONCLUSION}

From the results obtained in the present study, it could be concluded that there is a relationship between THK and SCC. The severity of THK was associated with an increase in SCC in milk and a greater risk of subclinical mastitis at the quarter level. As a result, milk production and its fat and protein percentages were decreased. Using THK assessment to detect milk SCC could be used as a simple and inexpensive tool to assess milk quality at the farm level. Also, to evaluate milking practices that cause the severity of THK, particularly in developing countries.

\section{CONFLICT OF INTEREST}

The authors certify that there is no conflict of interest with any financial, personal, or other relationships with the other people or organizations related to the material discussed in the manuscript.

\section{ACKNOWLEDGEMENT}

The authors would like to express their gratitude to Dr. Mohamed Abd El-Aziz Ibrahim, Professor of Animal Husbandry, Faculty of Agriculture, Cairo University, for his great help in the statistical analysis of data. Also, the authors would like to appreciate Dr. Rabie Ragab Sadek Professor of Animal Husbandry, Faculty of Agriculture, Cairo University, for his valuable advice through writing the manuscript. Funding of this study provided by Academy of Scientific Research and Technology (ASRT) through Agricultural Research in the Mediterranean (ARIMNET), project CDCMCT ARIMNet2 2017 for young researchers, grant agreement $N^{\circ} 618127$.

\section{REFERENCES}

Alhussien, M. N. \& A. K. Dang. 2018a. Milk somatic cells, factors influencing their release, future prospects, and practical utility in dairy animals: An overview. Vet. World. 11:562-577. https://doi.org/10.14202/vetworld.2018.562-577

Alhussien, M. N. \& A. K. Dang. 2018b. Diurnal rhythm in the counts and types of milk somatic cells, neutrophil phagocytosis and plasma cortisol levels in Karan Fries cows during different seasons and parity. Biol. Rhythm Res. 
49:187-199. https://doi.org/10.1080/09291016.2017.1350442

Ali, A. K. A. \& G. E. Shook. 1980. An optimum transformation for somatic cell concentration in milk. J. Dairy Sci. 63:487490. https://doi.org/10.3168/jds.S0022-0302(80)82959-6

Asadpour, R., H. Bagherniaee, M. Houshmandzad, H. Fatehi, A. Rafat, K. Nofouzi, \& K. Maftouni. 2015. Relationship between teat end hyperkeratosis with intra mammary infection and somatic cell counts in lactating dairy cattle. Rev. Med. Vet. 166:266-270.

Badiuzzaman, M., M. A. Samad, S. H. M. F. Siddiki, M. T. Islam, \& S. Saha. 2015. Subclinical mastitis in lactating cows: Comparison of four screening tests and effect of animal factors on its occurrence. Bangladesh J. Vet. Med. 13:41-50. https://doi.org/10.3329/bjvm.v13i2.26627

Bar, D., Y. T. Gröhn, G. Bennett, R. N. González, J. A. Hertl, H. F. Schulte, L. W. Tauer, F. L. Welcome, \& Y. H. Schukken. 2007. Effect of repeated episodes of generic clinical mastitis on milk yield in dairy cows. J. Dairy Sci. 90:4643-4653. https://doi.org/10.3168/jds.2007-0145

Bogucki, M. 2018. Effect of lactation stage and milking frequency on milk yield from udder quarters of cows. S. Afr. J. Anim. Sci. 48:636-642.

Cardozo, L. L., A. Thaler Neto, G. N. Souza, L. C. A. Picinin, N. C. Felipus, N. L. M. Reche, F. A. Schmidt, D. Werncke, \& E. E. Simon. 2015. Risk factors for the occurrence of new and chronic cases of subclinical mastitis in dairy herds in southern Brazil. J. Dairy Sci. 98:7675-7685. https://doi. org/10.3168/jds.2014-8913

De Vliegher, S., L. K. Fox, S. Piepers, S. McDougall, \& H. W. Barkema. 2012. Invited review: Mastitis in dairy heifers: Nature of the disease, potential impact, prevention, and control. J. Dairy Sci. 95:1025-1040. https://doi.org/10.3168/ jds.2010-4074

Egyptian Standards of Raw Milk. 2010. Raw milk specification, Egyptian organization for standardization and quality control. Ministry of Industry, Egypt. No. 7123.

Emre, B. \& E. Alaçam. 2015. The occurrence of teat hyperkeratosis in cows and its effect on milk somatic cell counts. Turkiye Klin. J. Vet. Sci. 6:1-6. https://doi.org/10.5336/ vetsci.2012-29182

Feltes, G. L., V. T. Michelotti, A. M. Prestes, A. P. Bravo, C. Bondan, M. D. A. Dornelles, F. C. Breda, \& P. R. N. Rorato. 2016. Milk production and percentages of fat and protein in Holstein breed cows raised in Rio Grande do Sul, Brazil. Cienc. Rural. 46:700-706. https://doi. org/10.1590/0103-8478cr20150465

Franzoi, M., C. L. Manuelian, M. Penasa, \& M. De Marchi. 2019. Effects of somatic cell score on milk yield and midinfrared predicted composition and technological traits of Brown Swiss, Holstein Friesian, and Simmental cattle breeds. J. Dairy Sci. 103:791-804. https://doi.org/10.3168/ jds.2019-16916

Guarín, J. F., M. G. Paixão, \& P. L. Ruegg. 2017. Association of anatomical characteristics of teats with quarter-level somatic cell count. J. Dairy Sci. 100:643-652. https://doi. org/10.3168/jds.2016-11459

Gurmessa, J. \& A. Melaku. 2012. Effect of lactation stage, pregnancy, parity and age on yield and major components of raw milk in bred cross Holstein Friesian cows. World J. Dairy Food Sci. 7:146-149.

Halasa, T., M. Nielen, A. P. W. De Roos, R. Van Hoorne, G. De Jong, T. J. G. M. Lam, T. Van Werven, \& H. Hogeveen. 2009. Production loss due to new subclinical mastitis in Dutch dairy cows estimated with a test-day model. J. Dairy Sci. 92:599-606. https://doi.org/10.3168/jds.2008-1564

Heinrichs, J., C. Jones, \& K. Bailey. 2016. Milk components: Understanding milk fat and protein variation in your dairy herd. https://extension.psu.edu/milk-componentsunderstanding-milk-fat-and-protein-variation-in-your- dairy-herd. [3 August 2018].

Juozaitiene, V., A. Juozaitis, J. Zymantiene, V. Oberauskas, A. Aniulienè, L. Kajokienè, A. Yilmaz, \& A. Simokaitienè. 2019. The effect of different levels of teat-end hyperkeratosis on mammary infrared thermograph and mastitis in dairy cows. Ankara Univ. Vet. Fak. Derg. 66:21-26. https:// doi.org/10.1501/Vetfak_0000002883

Khatun, M., R. M. Bruckmaier, P. C. Thomson, J. House, \& S. C. García. 2019. Suitability of somatic cell count, electrical conductivity, and lactate dehydrogenase activity in foremilk before versus after alveolar milk ejection for mastitis detection. J. Dairy Sci. 102:9200-9212. https://doi. org/10.3168/jds.2018-15752

Kul, E., A. Şahin, S. Atasever, E. Uğurlutepe, \& M. Soydaner. 2019. The effects of somatic cell count on milk yield and milk composition in Holstein cows. Vet. Arh. 89:143-154. https://doi.org/10.24099/vet.arhiv.0168

Le Maréchal, C., R. Thiéry, E. Vautor, \& Y. Le Loir. 2011. Mastitis impact on technological properties of milk and quality of milk products-a review. Dairy Sci. Technol. 91:247-282. https://doi.org/10.1007/s13594-011-0009-6

Manzi, M. D. P., D. B. Nobrega, P. Y. Faccioli, M. Z. Troncarelli, B. D. Menozzi, \& H. Langoni. 2012. Relationship between teat-end condition, udder cleanliness and bovine subclinical mastitis. Res. Vet. Sci. 93:430-434. https://doi. org/10.1016/j.rvsc.2011.05.010

Mein, G. A., F. Neijenhuis, W. F. Morgan, D. J. Reinemann, J. E. Hillerton, J. R. Baines, I. Ohnstad, M. D. Rasmussen, L. Timms, J. S. Britt, R. Farnsworth, N. Cook, \& T. Hemling. 2001. Evaluation of Bovine Teat Condition in Commercial Dairy Herds: 1. Non-Infectious Factors. AABB-NMC International Symposium Mastitis Milk Quality Proceeding, Vancouver, BC, Canada. p. 347-351.

Mein, G. A. 2012. The role of the milking machine in mastitis control. Vet. Clin. North Am. Food Anim. Pract. 28:307320. https://doi.org/10.1016/j.cvfa.2012.03.004

Miles, A. M., J. A. A. McArt, F. A. Leal Yepes, C. R. Stambuk, P. D. Virkler, \& H. J. Huson. 2019. Udder and teat conformational risk factors for elevated somatic cell count and clinical mastitis in New York Holsteins. Prev. Vet. Med. 163:7-13. https://doi.org/10.1016/j.prevetmed.2018.12.010

Mitev, J. E., Zh. I. Gergovska \& T. M. Miteva. 2012. Effect of teat end hyperkeratosis on milk somatic cell counts in Bulgarian Black-and-White dairy cattle. Bulg. J. Agric. Sci. 18:451-454.

Nasr, M. A. F., \& M. S. El-Tarabany. 2017. Impact of three THI levels on somatic cell count, milk yield and composition of multiparous Holstein cows in a subtropical region. J. Therm. Biol. 64:73-77. https://doi.org/10.1016/j. jtherbio.2017.01.004

Neijenhuis, F., H. W. Barkema, H. Hogeveen, \& J. P. T. M. Noordhuizen. 2000. Classification and longitudinal examination of callused teat ends in dairy cows. J. Dairy Sci. 83:2795-2804. https://doi.org/10.3168/jds. S0022-0302(00)75177-0

Nielsen, N. I., T. Larsen, M. Bjerring, \& K. L. Ingvartsen. 2005. Quarter health, milking interval, and sampling time during milking affect the concentration of milk constituents. J. Dairy Sci. 88:3186-3200. https://doi.org/10.3168/jds. S0022-0302(05)73002-2

Pinzón-Sánchez, C., \& P. L. Ruegg. 2011. Risk factors associated with short-term post-treatment outcomes of clinical mastitis. J. Dairy Sci. 94:3397-3410. https://doi.org/10.3168/ jds.2010-3925

Ríos-utrera, Á., R. C. Calderón-robles, \& J. R. Galavízrodríguez. 2013. Effects of breed, calving season and parity on milk yield, body weight and efficiency of dairy cows under subtropical conditions. Int. J. Anim. Vet. Adv. 5:226232. https://doi.org/10.19026/ijava.5.5602 
Ruegg, P. L., \& J. C. F. Pantoja. 2013. Understanding and using somatic cell counts to improve milk quality. Irish. J. Agric. Food Res. 52:101-117.

Sadeghi-sefidmazgi, A. \& F. Rayatdoost-baghal. 2014. Effects of herd management practices on somatic cell counts in an arid climate. Rev. Bras. Zootec. 43:499-504. https://doi. org/10.1590/S1516-35982014000900007

Sadek, R. R., G. Ashour, M. A. M. Ibrahim, \& A. M. Samoul. 2014. Effect of daily weight gain on age at first calving and subsequent milk yield of Holstein heifers in Egypt. J. Anim. Prod. 51:164-171. https://doi.org/10.21608/ejap.2014.93644

Sandrucci, A., L. Bava, M, Zucali, \& A. Tamburini. 2014. Management factors and cow traits influencing milk somatic cell counts and teat hyperkeratosis during different seasons. Rev. Bras. Zootec. 43:505-511. https://doi. org/10.1590/S1516-35982014000900008

Schwarz, D., U. S. Diesterbeck, K. Failing, S. König, K. Brügemann, M. Zschöck, W. Wolter, \& C. P. Czerny. 2010. Somatic cell counts and bacteriological status in quarter foremilk samples of cows in Hesse, Germany-a longitudinal study. J. Dairy Sci. 93:5716-5728. https://doi. org/10.3168/jds.2010-3223

Sebastino, K. B., H. Uribe, \& H. H. González. 2020. Effect of test year, parity number and days in milk on somatic cell count in dairy cows of Los Ríos region in Chile. Austral J. Vet. Sci. 52:1-7. https://doi.org/10.4067/S0719-81322020000100102

Sharma, N., N. K. Singh, \& M. S. Bhadwal. 2011. Relationship of somatic cell count and mastitis: An overview. AsianAustralas. J. Anim. Sci. 24:429-438. https://doi.org/10.5713/ ajas.2011.10233

Sharma, A., S. Sharma, N. Singh, V. Sharma, \& R. S. Pal. 2016. Impact of udder and teat morphometry on udder health in Tharparkar cows under climatic condition of hot arid region of Thar Desert. Trop. Anim. Health Prod. 48:16471652. https://doi.org/10.1007/s11250-016-1138-y

Silva, J. E. D., S. B. P. Barbosa, B. da S. Abreu, K. R. Santoro, E. C. D. Silva, Â. M. V. Batista, \& R. L. V. Martinez. 2018.
Effect of somatic cell count on milk yield and milk components in Holstein cows in a semi-arid climate in Brazil. Rev. Bras. Saude Prod. Anim. 19:391-402. https://doi. org/10.1590/s1519-99402018000400004

Singh, R. S., B. K. Bansal, \& D. K. Gupta. 2017. Relationship between teat morphological traits and subclinical mastitis in Frieswal dairy cows. Trop. Anim. Health Prod. 49:16231629. https://doi.org/10.1007/s11250-017-1368-7

Smith, K. L., Wooster, J. E. Hillerton, Compton, R. J. Harmon, \& A. Lexington. 2001. Guidelines on normal and abnormal raw milk based on somatic cell counts and signs of clinical mastitis. National Mastitis Council. http://www.nmconline.org/docs/abnmilk.

Vissio, C., S. A. Dieser, H. L. Agnelli, L. M. Odierno, \& A. J. Larriestra. 2014. Accuracy of the composite somatic cell count to detect intra-mammary infection in dairy cows using latent class analysis. Prev. Vet. Med. 113:547-555. https://doi.org/10.1016/j.prevetmed.2013.11.016

Wongpom, B., S. Koonawootrittriron, M. A. Elzo, \& T. Suwanasopee. 2017. Milk yield, fat yield and fat percentage associations in a Thai multibreed dairy population. Agric. Nat. Resour. 51:218-222. https://doi.org/10.1016/j. anres.2016.12.008

Yang, L., Q. Yang, M. Yi, Z. H. Pang, \& B. H. Xiong. 2013. Effects of seasonal change and parity on raw milk composition and related indices in Chinese Holstein cows in northern China. J. Dairy Sci. 96:6863-6869. https://doi.org/10.3168/ jds.2013-6846

Zeinhom, M. M. A., R. L. Abdel Aziz, A.N. Mohammed, \& U. Bernabucci. 2016. Impact of seasonal conditions on quality and pathogens content of milk in Friesian cows. Asian-Australas. J. Anim. Sci. 29:1207-1213. https://doi. org/10.5713/ajas.16.0143

Zoche-Golob, V., H. Haverkamp, J. H. Paduch, D. Klocke, C. Zinke, M. Hoedemaker, W. Heuwieser, \& V. Krömker. 2015. Longitudinal study of the effects of teat condition on the risk of new intramammary infections in dairy cows. J. Dairy Sci. 98:910-917. https://doi.org/10.3168/jds.2014-8446 